\title{
Aurora kinase and FGFR3 inhibition results in significant apoptosis in molecular subgroups of multiple myeloma
}

\author{
Utkarsh Painuly,1,2,*, Vijay Ramakrishnan ${ }^{1, *}$, Teresa Kimlinger ${ }^{1}$, Linda Wellik ${ }^{1}$, \\ Jessica Haug ${ }^{1}$, Wilson Gonsalves ${ }^{1}$, Lintao $\mathbf{B i}^{1,3}$, Zhongxia Huang ${ }^{1}$, S. Vincent \\ Rajkumar $^{1}$ and Shaji Kumar ${ }^{1}$ \\ ${ }^{1}$ Division of Hematology, Mayo Clinic, Rochester, MN, USA \\ ${ }^{2} 4$ th Department of Internal Medicine-Hematology University Hospital Hradec Kralove and Charles University in Prague, \\ Faculty of Medicine in Hradec Kralove, Hradec Králové, Czech Republic \\ ${ }^{3}$ The Department of Hematology and Oncology, China-Japan Union Hospital attached to JiLin University, Changchun, Jilin, \\ China \\ *These authors contributed equally to this work
}

Correspondence to: Shaji Kumar, email: kumar.shaji@mayo.edu

Keywords: multiple myeloma; FGFR3; Aurora kinase; apoptosis; proliferation

Received: February 15, $2016 \quad$ Accepted: September 15, $2018 \quad$ Published: October 02, 2018

Copyright: Painuly et al. This is an open-access article distributed under the terms of the Creative Commons Attribution License 3.0 (CC BY 3.0), which permits unrestricted use, distribution, and reproduction in any medium, provided the original author and source are credited.

\section{ABSTRACT}

\begin{abstract}
Aberrant expression of proteins involved in cell division is a constant feature in multiple myeloma (MM), especially in high-risk disease. Increasingly, therapy of myeloma is moving towards individualization based on underlying genetic abnormalities. Aurora kinases are important mediators of cell cycle and are up regulated in MM. Functional loss of Aurora kinases results in genetic instability and dysregulated division leading to cellular aneuploidy and growth arrest. We investigated the role of Aurora kinase inhibition in $M M$, using a small molecule inhibitor A1014907. Low nanomolar A1014907 concentrations induced aneuploidy in $M M$ cell lines independent of underlying cytogenetic abnormalities by inhibiting Aurora Kinases. However, A1014907 induced more pronounced and dose dependent apoptosis in cell lines with $t(4 ; 14)$ translocation. Translocation $t(4 ; 14)$ is observed in about $15 \%$ of patients with MM leading to constitutive activation of FGFR3 in twothirds of these patients. Further investigation of the mechanism of action of A1014907 revealed potent FGFR3 pathway inhibition only in the sensitive cell lines. Thus, our results show that aurora kinase inhibition causes cell cycle arrest and aneuploidy with minimal apoptosis whereas inhibiting both aurora kinase and FGFR3 activity induced potent apoptosis in MM cells. These results support clinical evaluation of A1014907 in MM patients with $t(4 ; 14)$ translocation and/or FGFR3 expression.
\end{abstract}

\section{INTRODUCTION}

Aurora kinases (A, B and C) are highly conserved serine threonine kinases whose functions mediate different stages of cell division [1]. Aurora A is localized to the centrosomes and spindle poles during mitosis and facilitates centrosome maturation, spindle assembly and chromosome separation [2-4]. Aurora B is localized to the centromere till metaphase and subsequently relocates to the spindle midbody through telophase and cytokinesis [5].
Aurora B along with survivin, borealin, and INCENP is a member of the chromosome passenger complex. This complex functions in several important steps in mitosis including chromosome condensation, spindle assembly checkpoint control and cytokinesis [6-8]. The function of Aurora kinase $\mathrm{C}$, is relatively less understood in mitosis. It is thought to function in the absence of Aurora kinase B [9]. Depletion of Aurora-A leads to mitotic arrest followed by the induction of polyploidy in cells lacking p53 [10]. Low levels of Aurora A contributes to decreased activity 
of Cyclin B/CDK1, a G2M regulatory protein complex, further contributing to cell cycle arrest $[11,12]$. During cell cycle progression, abnormally formed spindles are detected at mitotic checkpoint, which then arrests the cells in mitosis. Depletion of Aurora-B eliminates activation of mitotic checkpoint, leading to formation of tetraploid cells. As mitotic checkpoint remains inactivated, these cells fail to arrest at mitosis [13, 14].

Increased expression of Aurora kinases have been observed in various tumors including multiple myeloma (MM) $[15,16]$. The lack of expression of the aurora kinases in non-dividing cells and the increased expression in cancer cells makes this an attractive therapeutic target [15]. Aurora kinase as a therapeutic target in MM has been explored with several inhibitors in pre clinical setting, including ENMD-2076, MLN8237, AZD1152, AT9283 and VE-465 [17-21]. Out of these, AT9283 and VE465 are the only inhibitors that target both Aurora A and $\mathrm{B}$ kinases. None of these inhibitors are currently under clinical evaluation in MM.

We studied the role of Aurora A and B kinase inhibition in a heterogeneous group of MM cell lines using a small molecular inhibitor of Aurora Kinase A and B, A1014907. A1014907 induced G2M arrest and polyploidy in all MM cell lines indicating Aurora Kinase A and B inhibition. In particular, we observed increased sensitivity of cell lines with $\mathrm{t}(4 ; 14)$ translocation to A1014907. Upon further studies, we present clear evidence that in addition to aurora kinases, A1014907 inhibits FGFR3, a receptor overexpressed primarily in MM cells with $\mathrm{t}(4 ; 14)$ translocation.

\section{RESULTS}

\section{Cell lines with $\mathrm{t}(4 ; 14)$ translocation show increased sensitivity to A1014907}

We first assessed the cytotoxic effects of A1014907 on MM cells. For this, we treated a panel of MM cell lines with various doses of A1014907 for 72 hrs and examined the cytotoxicity induced by the drug. We observed that cell lines OPM2, KMS11, KMS18, KMS28BM, H929, KAS6, LP1, OPM1 and KMS34 were significantly more sensitive to A1014907 treatment when compared to the other cell lines examined (Figure 1A, 1B and 1E). The IC50 values are shown in Table 1. Similar differential effects were also seen when we performed thymidine incorporation assays to examine the anti-proliferative effects induced by A1014907 (Figure 1C, 1D and 1F). The IC50 values observed in proliferation assay are shown in Table 2 . The cell lines sensitive to A1014907 in both assays, namely, KMS11, KMS18, KMS28BM, H929, KAS6, LP1, OPM1 and KMS34 all have $\mathrm{t}(4 ; 14)$ translocation and express FGFR3. Thus at lower doses A1014907 is able to inhibit proliferation in both $\mathrm{t}(4 ; 14)$ as well as non $\mathrm{t}(4 ; 14)$ cells suggestive of aurora kinase inhibition in both these groups of cell lines. Out of the $t(4 ; 14)$ cell lines, KMS28BM, KMS34, H929 and KAS6 all express wild type FGFR3 and KMS11 (Y373C), KMS18 (G382D) and OPM1 and OPM2 (K560E) have activating mutations in FGFR3. LP1 has a non activating mutation in FGFR3 (F384L).

\section{A1014907 is effective in the presence of tumor promoting bone marrow stromal cells}

Bone marrow stromal cells (BMSCs) are important cellular components of the tumor microenvironment, whose interaction with MM cells contribute to disease progression and resistance to existing therapies [22]. We therefore examined if A1014907 was able to overcome the protective effects of BMSCs. We observed that A1014907 was able to inhibit proliferation of MM cells even in the presence of BMSCs in both $\mathrm{t}(4 ; 14)$ (Figure 2A and 2B) and non $\mathrm{t}(4 ; 14)$ cells (Figure $2 \mathrm{C}$ ).

\section{A1014907 induces polyploidy in all MM cell lines and pronounced apoptotic cell death in $t(4 ; 14)$ MM cell lines}

We next assessed if A1014907 induced cell division aberrations in both $\mathrm{t}(4 ; 14)$ as well as non $\mathrm{t}(4 ; 14)$ cells. For this experiment, we used KMS11, a $\mathrm{t}(4 ; 14)$ and MM1S, a non $\mathrm{t}(4 ; 14)$ cell line. G2M arrest and polyploidy was observed in both cell lines. This was evident as early as 24 hours with $10 \mathrm{nM}$ A1014907 treatment. (Figure 3A and $3 \mathrm{~B})$. To confirm that the appearance of the $8 \mathrm{~N}$ peak was due to the ability of A1014907 to induce polyploidy and not because of the drug's ability to cause G2/M arrest, we treated MM1S cells with TG101209, a Jak2 inhibitor that we had shown in an earlier study to induce G2/M arrest. Results showed that TG101209 induced G2/M arrest without causing polyploidy further confirming that A1014907 does indeed induce polyploidy (Supplementary Figure 1). Morphological analysis showed that untreated control cells appeared to be of uniform cell and nuclear size (Figure 3C and 3D). However, A1014907 caused the cells to increase in size with varied nuclear numbers/sizes within each cell indicative of cell division abnormality and possibly aurora kinase inhibition. (Figure 3C and 3D). Given that A1014907 induced more potent cell death in cells with $\mathrm{t}(4 ; 14)$ translocation than in cells lacking this translocation, we next performed assays to confirm if the cell death occurred through induction of apoptosis. For this, we treated KMS11 and MM1S cells with indicated concentrations of A1014907 for various time points. We observed that A1014907 induced potent apoptotic cell death in KMS11 cells (Figure 3E and 3F). However, MM1S and U266 cells showed resistance to A1014907 treatment with minimal increase in apoptosis (Figure $3 \mathrm{G}$, $3 \mathrm{H}$ and Supplementary Figure 2). 


\section{A1014907 shows enhanced activity against patient cells with $t(4 ; 14)$ translocation}

We then examined apoptosis induced by A1014907 on MM patient cells with or without the $\mathrm{t}(4 ; 14)$ translocation. For this, we treated non $\mathrm{t}(4 ; 14)(n=15)$ and patients with $\mathrm{t}(4 ; 14)$ translocation $(n=6)$ with A1014907 for $72 \mathrm{hrs}$. We then measured apoptosis by annexin/PI staining. Our results showed a trend towards enhanced activity of A1014907 on patients with $\mathrm{t}(4 ; 14)$ translocation (Figure 3I) though the difference was statistically insignificant due to small patient numbers. The patient disease characteristics are included in Table 3.

\section{A1014907 inhibits Aurora Kinases A and B and proteins involved in cell cycle machinery}

Next, we examined the mechanism of action of A1014907. We treated two $t(4 ; 14)$ cell lines KMS11 and KMS18 and one non $\mathrm{t}(4 ; 14)$ cell line MM1S cells with indicated concentrations of A1014907 and examined the expression levels of aurora kinases and proteins involved in cell cycle progression. As expected, we saw down regulation of phospho Aurora $\mathrm{A}$ and phospho Histone H3, a substrate of Aurora B and a biomarker of mitosis in all the three cell lines (Figure 4A-4C). Surprisingly, we also observed that A1014907 caused down regulation of total Aurora A. While we do not know the mechanism contributing to this, we speculate that A1014907 acts by blocking aurora A phosphorylation and in addition also by inducing the degradation of Aurora A. Our results from Figure 3A and 3B clearly showed that A1014907 caused accumulation of cells in the G2M stage of the cell cycle in addition to polyploidy. We therefore examined the levels of proteins involved in cell cycle progression. A1014907 treatment reduced levels of Cdc2, cyclins A and B (Figure 4A-4C). Cdc2-Cyclin A complex regulates late $\mathrm{S}$ phase and early $\mathrm{M}$ phase while Cdc2-Cyclin B complex regulates $\mathrm{M}$ phase of the cell cycle. Thus, our data suggests that reduction in the level of $\mathrm{Cdc} 2$ and its binding partners
A
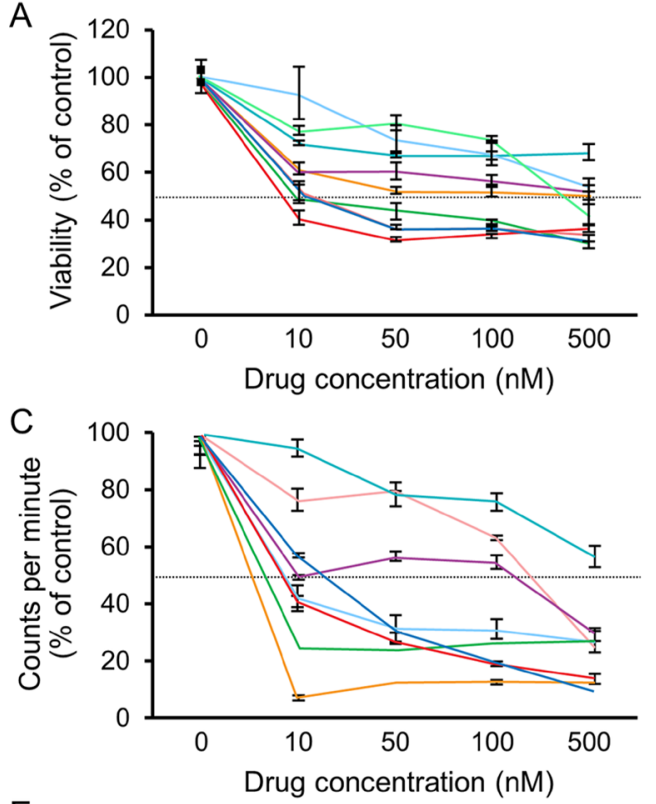

E

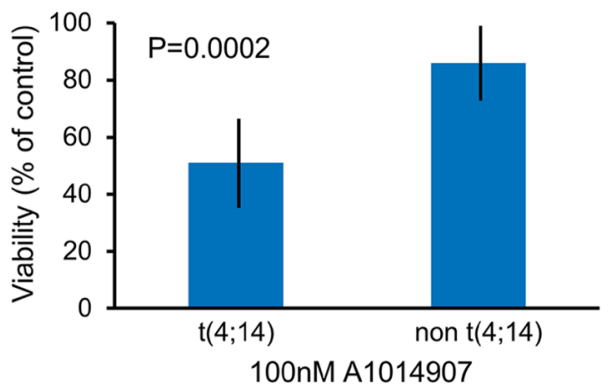

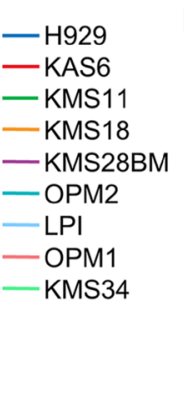

B
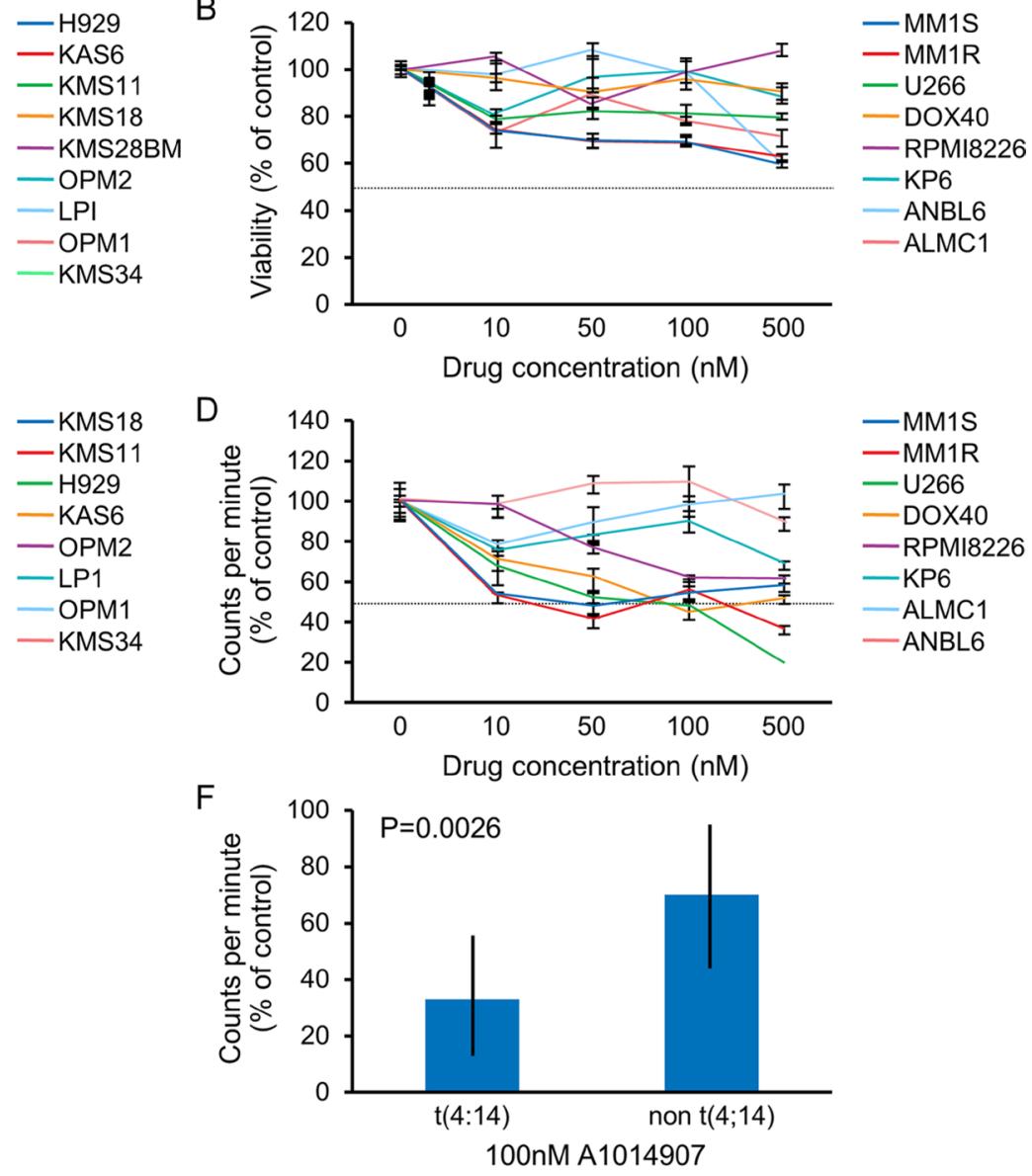

Figure 1: When MM cell lines were incubated with indicated doses of A1014907 for $72 \mathrm{hrs,} \mathrm{we} \mathrm{observed} \mathrm{potent} \mathrm{dose} \mathrm{dependent} \mathrm{decrease}$ in (A) viability and $(\mathbf{C})$ proliferation in $\mathrm{t}(4 ; 14) \mathrm{MM}$ cell lines and relatively less decrease in $(\mathbf{B})$ viability and (D) proliferation in non $\mathrm{t}(4 ; 14)$ MM cell lines. (E) Mean \% viability and (F) Mean \% proliferation of all $\mathrm{t}(4 ; 14)$ cell lines and all non $\mathrm{t}(4 ; 14)$ cell lines after treatment with $100 \mathrm{nM}$ of A1014907 for 72 hrs shows significantly more cell death and growth arrest respectively in the $\mathrm{t}(4 ; 14)$ cell lines. $P$ values show statistical significance. 
Table 1: IC50 values of A1014907 on both the $t(4 ; 14)$ and non $t(4 ; 14)$ cell lines used in this study

\begin{tabular}{lccc}
\hline $\begin{array}{l}\text { t(4;14) } \\
\text { translocation and FGFR3 mutational status }\end{array}$ & IC50 & $\begin{array}{c}\text { Non t(4;14) } \\
\text { translocation }\end{array}$ & IC50 \\
\hline Kas6 (wt FGFR3) & $10 \mathrm{nM}$ & MM1S & $>500 \mathrm{nM}$ \\
KMS11 (Y373C) & $50 \mathrm{nM}$ & MM1R & $>500 \mathrm{nM}$ \\
KMS18 (G382D) & $500 \mathrm{nM}$ & DOX40 & $>1000 \mathrm{nM}$ \\
KMS28BM (wt FGFR3) & $500 \mathrm{nM}$ & RPMI8226 & $>1000 \mathrm{nM}$ \\
H929 (wt FGFR3) & $10 \mathrm{nM}$ & $\mathrm{U} 266$ & $>500 \mathrm{nM}$ \\
OPM2 (K560E) & $>500 \mathrm{nM}$ & KP6 & $>500 \mathrm{nM}$ \\
KMS34 (wt FGFR3) & $500 \mathrm{nM}$ & ALMC1 & $>500 \mathrm{nM}$ \\
LPI (F384L) & $>500 \mathrm{nM}$ & ANBL6 & \\
OPM1 (K560E) & $50 \mathrm{nM}$ & & \\
\hline
\end{tabular}

Results show enhanced cytotoxicity of A1014907 on cell lines with t(4;14) translocation.

Table 2: IC50 values of A1014907 on both the $t(4 ; 14)$ and non $t(4 ; 14)$ cell lines used in this study as determined by thymidine incorporation assays

\begin{tabular}{lccc}
\hline $\begin{array}{l}\text { t(4;14) } \\
\text { translocation and FGFR3 mutational status }\end{array}$ & IC50 & $\begin{array}{c}\text { Non t(4;14) } \\
\text { translocation }\end{array}$ & IC50 \\
\hline Kas6 (wt FGFR3) & $10 \mathrm{nM}$ & MM1S & $50 \mathrm{nM}$ \\
KMS11 (Y373C) & $10 \mathrm{nM}$ & MM1R & $50 \mathrm{nM}$ \\
KMS18 (G382D) & $50 \mathrm{nM}$ & DOX40 & $100 \mathrm{nM}$ \\
KMS28BM (wt FGFR3) & $50 \mathrm{nM}$ & RPMI8226 & $>500 \mathrm{nM}$ \\
H929 (wt FGFR3) & $10 \mathrm{nM}$ & U266 & $50 \mathrm{nM}$ \\
OPM2 (K560E) & $500 \mathrm{nM}$ & KP6 & $>500 \mathrm{nM}$ \\
KMS34 (wt FGFR3) & $500 \mathrm{nM}$ & ALMC1 & $>500 \mathrm{nM}$ \\
LPI (F384L) & $>500 \mathrm{nM}$ & ANBL6 & $>500 \mathrm{nM}$ \\
OPM1 (K560E) & $10 \mathrm{nM}$ & & \\
\hline
\end{tabular}

The IC50 values as determined by this assay were not very different between the two groups of cell lines though $\mathrm{t}(4 ; 14)$ cells did show enhanced sensitivity to A1014907.

cyclins A and B could be major factors contributing to the observed G2M arrest (Figure 3A and 3B). Cdc2-Cyclin B complex is a key regulator of nuclear envelope breakdown $[23,24]$. Its inhibition could further contribute to a lack of or abnormal karyokinesis, producing abnormal cells with unequal DNA content (Figure 3C and 3D).

\section{A1014907 inhibits FGFR3 in $t(4 ; 14)$ cells promoting apoptosis}

Our results so far suggest that A1014907 inhibits the proliferation and causes polyploidy in all MM cell lines (Figure 1C and 1D and Figure 3A and 3B) through the down regulation of Auroras A and B. (Figure 4A-4C). However, A1014907 induced significant cell death only in $\mathrm{MM}$ cells with $\mathrm{t}(4 ; 14)$ translocation (Figure $1 \mathrm{~A}$ and $1 \mathrm{~B}$ and Figure $3 \mathrm{E}-3 \mathrm{H})$, which is associated with increased FGFR3 expression [25]. We therefore hypothesized that A1014907, in addition to being an aurora kinase inhibitor was also able to inhibit FGFR3 causing increased apoptosis in cells with $\mathrm{t}(4 ; 14)$ translocation. We performed a receptor tyrosine kinase (RTK) array using KMS11 cells left untreated or treated with indicated dose of A1014907. The results showed down regulation of pFGFR3 by A1014907 (Figure 5A).

Activated FGFR3 can cause the up regulation of various signaling pathways including the PLC $\gamma / \mathrm{PKC}$, Jak2/Stat3, PI3K/Akt, and Mek/Erk pathways [26]. To better understand which of these signaling pathways are involved in A1014907 induced apoptosis, we performed western blotting using lysates from KMS11, KMS18 and MM1S cells. We observed inhibition of pPLC $\gamma, \mathrm{pPKC}$ and 
pStat3 in cell lines KMS11 and KMS18, which are both sensitive to A1014907 (Figure 5B and 5C), In MM1S, the cell line lacking FGFR3 expression, we did not observe down regulation of any of these proteins again suggesting specific inhibition of FGFR3 by A1014907 (Figure 5D).

Next, we examined levels of the $\mathrm{Bcl} 2$ family of anti apoptotic proteins and observed down regulation of $\mathrm{Bcl}-2$ and $\mathrm{Bcl}-\mathrm{Xl}$ in $\mathrm{KMS} 11$ and $\mathrm{KMS} 18$ respectively (Figure 5E and 5F). In addition, we observed activation of the intrinsic apoptotic pathway as shown by increased levels of cleaved caspases 9 and 3 (Figure 5E and 5F) and inactivation of PARP (Figure 5E and 5F) all indicating increase in cell death. It must be noted that such differences in apoptotic proteins were absent in MM1S cells (Figure 5G).

\section{A1014907 activity is dependent on FGFR3 expression but not $t(4 ; 14)$ translocation}

To further confirm that A1014907 inhibits FGFR3, we checked the sensitivity of INA6, a non $t(4 ; 14)$ line that overexpresses FGFR3 to A1014907. We observed that INA6 was sensitive to A1014907 like the $\mathrm{t}(4 ; 14)$ cell lines (Figure 6A). To further confirm that the activity of

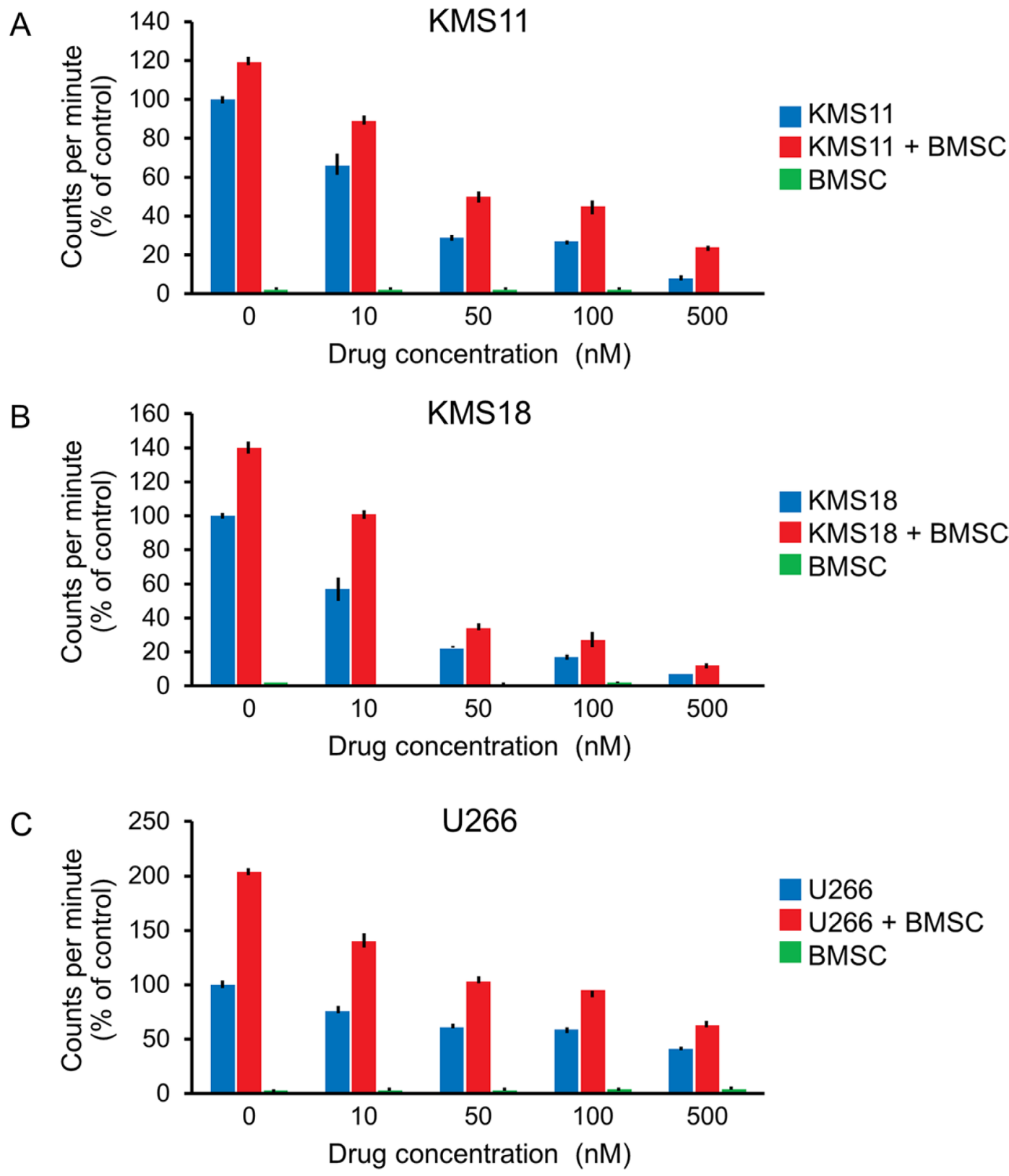

Figure 2: t(4;14) MM cell lines KMS11 and KMS18 and non t(4;14) MM cell line U266 were co-cultured with BMSCs derived from a MM patient followed by treatment with indicated doses of A1014907. As shown in (A-C), A1014907 was able to overcome the tumor protective effects of the BMSCs and inhibit the proliferation of MM cells even in the presence of BMSCs. 
A1014907 is dependent on FGFR3 expression and not due to the presence of $t(4 ; 14)$ translocation, we examined the effect of A1014907 on two MM cell lines JIM2 and JIM3, both of which are $t(4 ; 14)$ cell lines but negative for FGFR3 expression. A1014907 was unable to induce pronounced cell death in both these cell lines (Figure 6A). Recently, it was shown that Chronic Lymphocytic Leukemia (CLL) B cells express FGFR3, which potentiates their growth and survival [27]. We therefore treated CLL B cells from two patients with indicated doses of A1014907. We observed clear induction of cell death in both these patients (Figure 6B). Both the patients were positive for FGFR3 expression as determined by flow cytometry (data not shown). Taken together, we show that A1014907 induces cell death in FGFR3 expressing MM cells. FGFR3 expression could therefore serve as a biomarker to predict for sensitivity to A1014907.

\section{DISCUSSION}

MM is a genetically heterogeneous disease with about $50 \%$ of patients presenting with translocations involving the Immunoglobulin heavy chain (IgH) locus, often called the non hyperdiploid group and the remaining with trisomies of odd numbered chromosomes, often called the hyperdiploid group [28-30]. The common translocations observed in MM patients in the order of decreasing frequency include $\mathrm{t}(11 ; 14), \mathrm{t}(4 ; 14), \mathrm{t}(14 ; 16)$, $\mathrm{t}(6 ; 14)$ and $\mathrm{t}(14 ; 20)$ [29]. Almost all these patients express high levels of at least one D-type cyclin, thus contributing to cell cycle checkpoint abnormalities [31-33]. In addition, aurora kinases are aberrantly expressed in myeloma further adding to abnormalities in the cell division process [16]. Here, we have examined the preclinical activity of a novel aurora kinase inhibitor A1014907. Our findings
A

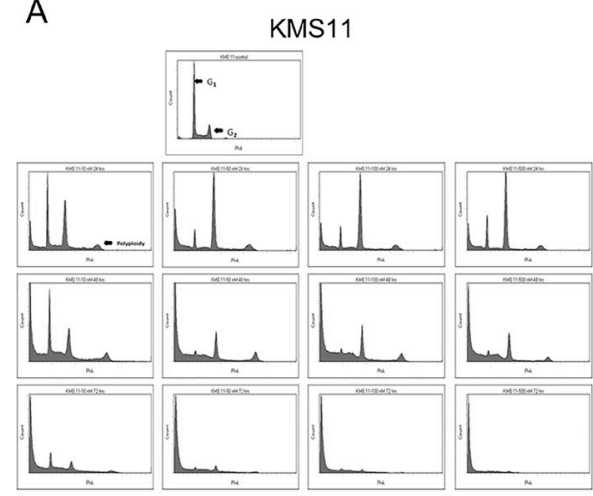

B

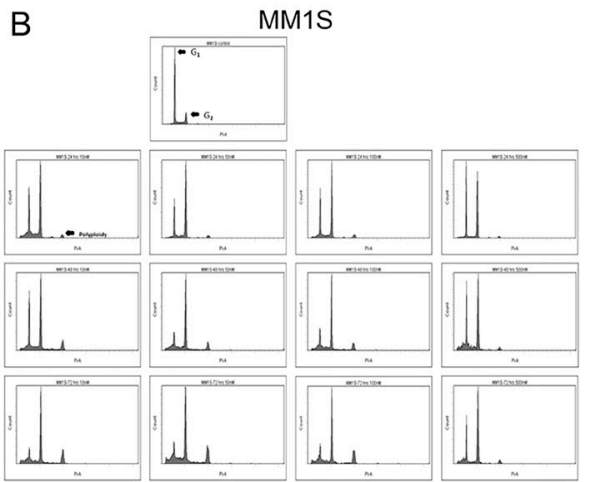

C

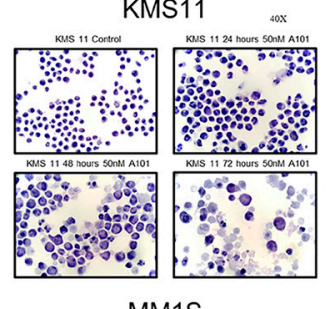

D

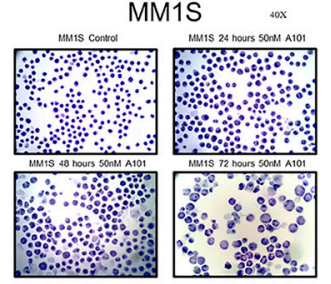

E
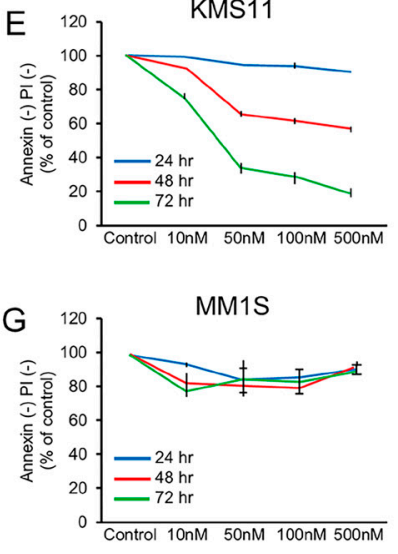

$\mathrm{F}$
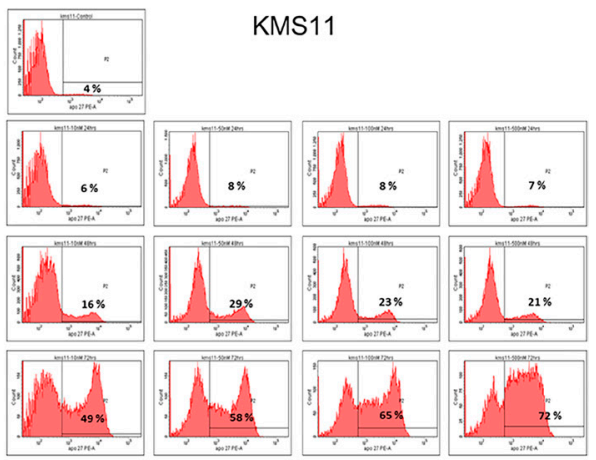

$\mathrm{H}$
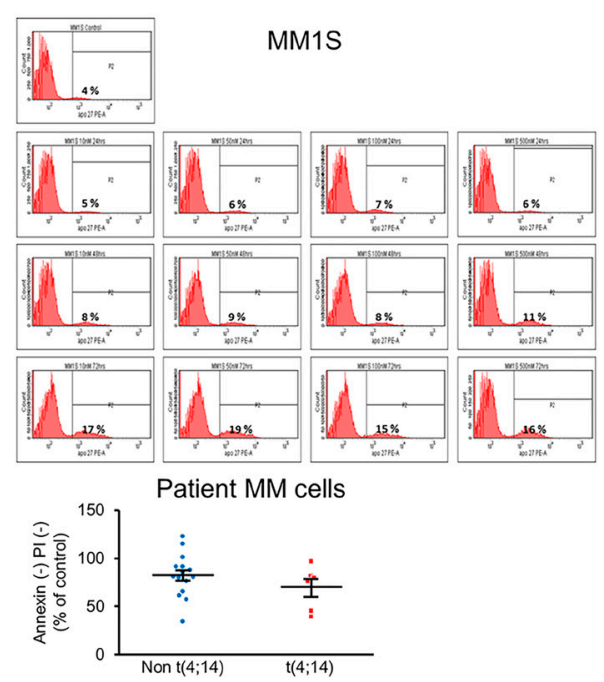

Figure 3: When (A and C) a t(4;14) MM cell line KMS11 and (B and D) a non t(4;14) MM cell line MM1S were treated with indicated doses of A1014907, we observed G2M arrest followed by polyploidy in both cell lines. In (A) KMS11, we observed G2M arrest at 24 hrs and polyploidy at 24 and $48 \mathrm{hrs}$ and increased apoptosis at $72 \mathrm{hrs}$. In (B) MM1S, we observed prolonged G2M arrest and polyploidy at all time points with very little apoptosis. In (C and D) we observed that A1014907 caused an increase in cell size with varying nuclear numbers and sizes typically seen during defects in cell division in both KMS11 and MM1S cells. Pictures were taken at 40× magnification. When $(\mathbf{E}$ and $\mathbf{F})$ KMS11 and (G and $\mathbf{H})$ MM1S were treated with indicated doses of A1014907, we observed profound apoptosis in KMS11 cells as evidenced by (E) annexin/PI staining and (F) Apo 2.7 staining. This increase in annexin/PI and Apo 2.7 positivity was not observed in MM1S cells ( $\mathrm{G}$ and $\mathrm{H}$ respectively). (I). We treated plasma cells from 15 patients without $\mathrm{t}(4 ; 14)$ translocation and 6 MM patients with $\mathrm{t}(4 ; 14)$ translocation with $1000 \mathrm{nM}$ of A1014907 for $72 \mathrm{hrs}$. Following this, annexin/PI staining was performed to examine apoptosis induced by the drug. 
Table 3: The patients used in this study and their disease characteristics

\begin{tabular}{|c|c|c|c|c|c|c|c|c|c|c|}
\hline $\begin{array}{l}\text { Patient } \\
\#\end{array}$ & $\begin{array}{l}\text { Disease } \\
\text { stage }\end{array}$ & Disease State & $\begin{array}{c}\text { No. of } \\
\text { prior } \\
\text { therapies }\end{array}$ & $\begin{array}{l}\text { Prior } \\
\text { ASCT }\end{array}$ & Cytogenetics & $t(4 ; 14)$ & $\begin{array}{c}\text { Para } \\
\text { protein }\end{array}$ & ВМРС\% & $\begin{array}{l}\text { Labelling } \\
\text { Index }\end{array}$ & $\begin{array}{c}\text { Viability } \\
(\% \text { of } \\
\text { control } \\
\text { at } 1 \mu \mathrm{M})\end{array}$ \\
\hline 1 & MGUS & no treatment & No & No & Trisomies & No & IgG kappa & 5 & 1.4 & 123.1 \\
\hline 2 & SMM & no treatment & No & No & Trisomies & No & IgG kappa & 30 & 0.2 & 65.8 \\
\hline 3 & SMM & no treatment & No & No & Del13, t(4;14), +1q & Yes & $\begin{array}{c}\operatorname{IgG} \\
\text { lambda }\end{array}$ & 20 & 1.2 & 62.2 \\
\hline 4 & SMM & no treatment & No & No & $\mathrm{t}(11 ; 14)$ & No & IgG kappa & 30 & 0.2 & 77.5 \\
\hline 5 & SMM & no treatment & No & No & Del13, trisomies & No & IgG kappa & 10 & 0.3 & 91.8 \\
\hline 6 & $\mathrm{MM}$ & Newly diagnosed & None & No & Trisomies & No & IgG kappa & 30 & 0.9 & 115.8 \\
\hline 7 & MM & Newly diagnosed & None & No & Normal & No & IgG kappa & 20 & 0.1 & 82.4 \\
\hline 8 & MM & Newly diagnosed & None & No & Trisomies & No & IgG kappa & 90 & 1.1 & 88.6 \\
\hline 9 & MM & Newly diagnosed & None & No & Normal & No & $\begin{array}{c}\operatorname{IgA} \\
\text { lambda }\end{array}$ & 5 & 2.2 & 80.6 \\
\hline 10 & $\begin{array}{l}\text { Relapsed } \\
\text { MM }\end{array}$ & Active relapse & 4 & Yes & $\begin{array}{l}\text { Del13, Del17p, } \\
\text { trisomies }\end{array}$ & No & IgG kappa & 30 & 10.5 & 34.1 \\
\hline 11 & $\begin{array}{l}\text { Relapsed } \\
\text { MM }\end{array}$ & Active relapse & 2 & Yes & Trisomies & No & $\begin{array}{c}\operatorname{IgG} \\
\text { lambda }\end{array}$ & 20 & & 91.3 \\
\hline 12 & MM & Newly diagnosed & None & No & Trisomies & No & IgG kappa & 30 & 1.1 & 81.1 \\
\hline 13 & $\begin{array}{l}\text { Relapsed } \\
\text { MM }\end{array}$ & Active relapse & 4 & Yes & Del13, Del14 & No & $\begin{array}{c}\operatorname{IgG} \\
\text { lambda }\end{array}$ & 25 & 0.6 & 102.4 \\
\hline 14 & $\begin{array}{l}\text { Relapsed } \\
\text { MM }\end{array}$ & Responding dz & 5 & Yes & $\begin{array}{c}\text { Del13, Del17p, } \\
\text { Trisomies }\end{array}$ & No & IgG kappa & 0 & N/A & 86.8 \\
\hline 15 & $\begin{array}{l}\text { Relapsed } \\
\text { MM }\end{array}$ & Responding dz & 9 & Yes & del13, t $(11 ; 14)$ & No & Lambda & 5 & 1.2 & 58.2 \\
\hline 16 & $\begin{array}{l}\text { Relapsed } \\
\text { MM }\end{array}$ & Active relapse & 2 & No & del13, t $(4 ; 14)$ & Yes & IgA kappa & 90 & 2.1 & 76.7 \\
\hline 17 & $\begin{array}{l}\text { Relapsed } \\
\text { MM }\end{array}$ & Responding dz & 12 & Yes & del13, t $(4 ; 14)$ & Yes & $\begin{array}{c}\operatorname{IgD} \\
\text { lambda }\end{array}$ & 30 & 2.8 & 81.8 \\
\hline 18 & MM & Responding dz & 1 & No & del13, t $(4 ; 14)$ & Yes & $\begin{array}{c}\operatorname{IgG} \\
\text { lambda }\end{array}$ & 5 & 1.4 & 39.4 \\
\hline 19 & $\mathrm{MM}$ & Responding dz & 1 & No & del13, t $(4 ; 14)$ & Yes & IgA kappa & 10 & 0.8 & 44.9 \\
\hline 20 & $\begin{array}{l}\text { Relapsed } \\
\text { MM }\end{array}$ & Responding dz & 8 & Yes & $\mathrm{t}(4 ; 14)$, Trisomies & Yes & $\begin{array}{c}\operatorname{IgG} \\
\text { lambda }\end{array}$ & 90 & 1.5 & 79.2 \\
\hline 21 & $\begin{array}{l}\text { Relapsed } \\
\text { MM }\end{array}$ & Active relapse & 3 & Yes & $\begin{array}{c}\text { del13, t }(4 ; 14), \\
\text { Trisomies }\end{array}$ & Yes & IgG kappa & 10 & 0.8 & 96.7 \\
\hline
\end{tabular}

show that aurora kinase inhibition by A1014907 causes potent cell cycle arrest and polyploidy across all MM cell lines evaluated. However, aurora kinase inhibition alone appears to be insufficient to induce significant apoptosis. In addition to being an aurora kinase inhibitor, A1014907 is able to potently inhibit FGFR3. Simultaneous inhibition of Aurora kinases along with FGFR3 signaling induces cell cycle arrest, polyploidy and also apoptosis in FGFR3 expressing cells.

$\mathrm{t}(4 ; 14)$ is the second most common translocation observed in MM patients with a frequency of $15 \%$ [29]. Recently, it has been shown that MM patients presenting with a combination of International Scoring System 3 , high lactate dehydrogenase and $t(4 ; 14)$ and/or del (17p) treated with novel agents and autologous stem cell transplantation are at a high risk of progression and death [34]. Therefore, therapies that can overcome the adverse prognosis associated with $\mathrm{t}(4 ; 14)$ translocations are urgently required. Prior studies have shown that MM patients and cell lines with $t(4 ; 14)$ have a high centrosome index (CI) and overexpress aurora kinases [16]. We therefore expected to observe increased activity of A1014907 on MM cell lines and patients with $\mathrm{t}(4 ; 14)$. However, we observed a dramatic difference in the sensitivity of $t(4 ; 14)$ containing $M M$ cell lines when compared with the non $\mathrm{t}(4 ; 14)$ cell lines. This is unlikely to be explained merely by aurora kinase inhibition. Aurora kinase inhibitors have been examined as anti-MM agents in other studies and a few such inhibitors inhibited other receptor tyrosine kinases (RTKs) in addition to aurora kinases $[17,20]$. We therefore hypothesized that A1014907 inhibited FGFR3 expressed in about two-thirds 
of patients with $\mathrm{t}(4 ; 14)$ and in several MM cell lines with $\mathrm{t}(4 ; 14)$. Our results show that A1014907 inhibits aurora kinases and FGFR3. In cells lacking FGFR3 expression, A1014907 caused cell cycle arrest in majority of them but failed to induce marked apoptosis. In cells expressing wt FGFR3 or those with activating mutations in FGFR3 (Y373C or G382D), A1014907 caused potent cell cycle arrest and in addition pronounced apoptosis. Furthermore, we dissected the FGFR3 mediated down stream pathways and showed clear evidence that FGFR3 inhibition by A1014907 resulted in down regulation of both the PLC $\gamma /$ PKC and Stat3 signaling pathways leading to apoptosis induction in these cell lines. FGFR3 is also observed in $\mathrm{MM}$ independent of the $\mathrm{t}(4 ; 14)$ translocation $[35,36]$ and hence A1014907 could also be effective in those patients.

Taken together, our results clearly show preferential activity of A1014907 on MM cells with FGFR3 expression. $\mathrm{t}(4 ; 14)$. Clinical evaluation of A1014907 on relapsed/refractory MM patients with $\mathrm{t}(4 ; 14)$ and/or FGFR3 expression is planned.

\section{MATERIALS AND METHODS}

\section{MM cell lines and patient cells}

Cell lines MM1S, MM1R, RPMI8226, OPM2 and U266, were kindly provided by Dr. Jonathan Keats (TGen, Phoenix, AZ). Kas6 was kindly provided by Dr. John Lust (Mayo Clinic, Rochester, MN). KMS11, KMS18, KMS28BM, KMS34, LP1, OPM1, JIM2, JIM3 and INA6 were kindly provided by Dr. Leif Bergsagel (Mayo Clinic, Scottsdale, AZ). H929 was purchased from ATCC (Manassas, VA, USA) and DOX40 was kindly provided by Dr. William Dalton (Moffitt Cancer Center, Tampa, FL, USA). ALMC1, ANBL6 and KP6 were kindly provided by Dr. Diane Jelinek (Mayo Clinic, Rochester, MN). All cell lines except Kas6, KP6, ANBL6, ALMC1 and INA6 were cultured in RPMI 1640 media (Mediatech Inc., Manassas, VA) containing $2 \mathrm{mM}$ L-glutamine (Invitrogen, Grand Island, NY), $100 \mathrm{U} / \mathrm{mL}$ penicillin, $100 \mu \mathrm{g} / \mathrm{mL}$ streptomycin and $10 \%$ fetal bovine serum (Mediatech, Inc.). Kas6 and INA6 were cultured in same media but in the presence of $4 \mathrm{ng} / \mathrm{mL}$ of IL6 and $1 \mathrm{ng} / \mathrm{ml}$ IL6 respectively (R\&D Systems, Inc., Minneapolis, MN). ALMC1, ANBL6 and KP6 were cultured in IMDM media (Invitrogen) containing $2 \mathrm{mM}$ L-glutamine (Invitrogen), $100 \mathrm{U} / \mathrm{ml}$ penicillin, $100 \mu \mathrm{g} / \mathrm{mL}$ streptomycin, 10\% fetal bovine serum (Mediatech, Inc.) and supplemented with $1 \mathrm{ng} / \mathrm{ml}$ IL6 (R\&D Systems). Bone marrow aspirates were obtained from MM patients after informed consent under a protocol approved by the Mayo Clinic Institutional Review Board in adherence with the Declaration of Helsinki. Samples were processed to obtain MM cells or bone marrow stromal cells (BMSCs) as detailed elsewhere [37]. CLL B-cells were obtained after informed consent under a protocol approved by the Mayo Clinic Institutional Review Board in adherence with the Declaration of Helsinki. Samples were processed as mentioned elsewhere.
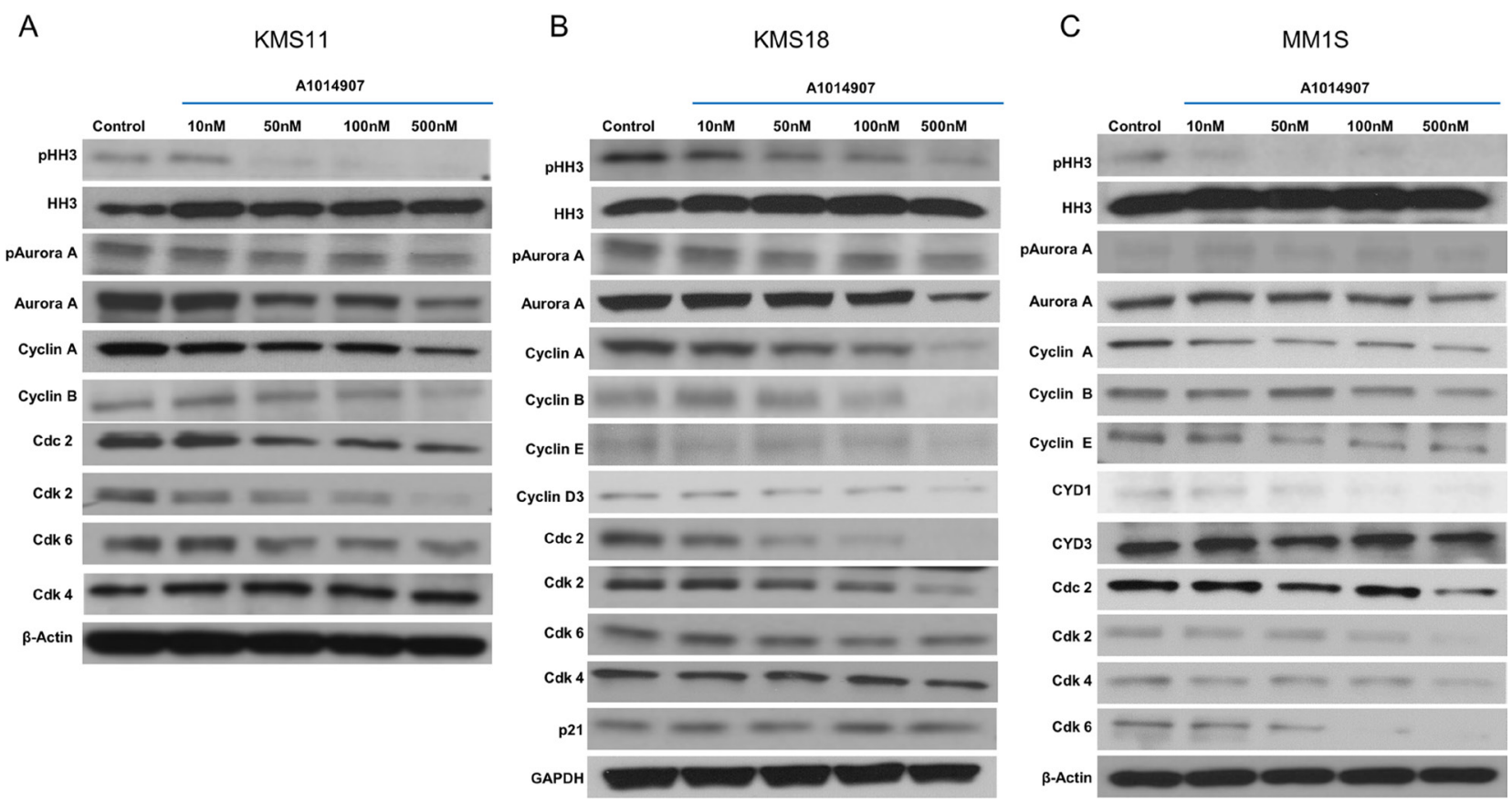

Figure 4: (A) KMS11, (B) KMS18 and (C) MM1S cells were incubated with indicated concentrations of A1014907 for 48 hrs and the expression levels of $\mathrm{pHH} 3$, pAuroraA, the various cyclins and cyclin dependent kinases were examined by western blots. 


\section{Drugs}

A1014907 was synthesized and provided by Abbott Laboratories Ltd under a Material Transfer Agreement (MTA). Stock solutions were made in DMSO, diluted in RPMI-1640 and subsequently stored at $-20^{\circ} \mathrm{C}$.

\section{MTT and proliferation assays}

Cytotoxic effects of A1014907 were measured using 3-(4, 5-dimethylthiazol-2-yl)-2, 5-diphenyl tetrasodium bromide (MTT) (Chemicon International Inc., Temecula, CA) colorimetric assay as described earlier [38-40]. Tritiated thmidine uptake assays were utilized to assess the anti-proliferative effects of A1014907 on MM cells when cultured either alone or in combination with BMSCs as described earlier [38-40].

\section{Morphological analysis}

Cells were fixed on glass slides using methanol. Slides were dried and deparaffinized followed by staining with Hematoxylin dye. Stained slides were rinsed, dehydrated using ethanol and xylene and finally mounted with resinous mounting medium. Microscopic images were taken at $40 \times$ magnification highlighting morphological changes post A1014907 treatment.

\section{Cell cycle analysis}

Cells were treated with indicated doses of A1014907 for 24, 48 or 72 hrs. Cells were harvested, counted and washed with PBS following which $2 \mathrm{ml}$ of cold $85 \%$ ethanol was added to the pellet while the tubes were vortexed. The tubes were left at $4^{\circ} \mathrm{C}$ overnight. Subsequently, the cells were pelleted and washed twice with PBS. The pellet was then resuspended in $0.1 \mathrm{ml}$ of $5 \mu \mathrm{g} / \mathrm{ml}$ RNase (Sigma-Aldrich, St. Louis, MO) and incubated at $37^{\circ} \mathrm{C}$ for 30 minutes. PBS $(0.9 \mathrm{ml})$ and $10 \mu \mathrm{l}$ of $1 \mathrm{mg} / \mathrm{ml}$ propidium iodide (PI) (Sigma-Aldrich) were added and samples were held at $4^{\circ} \mathrm{C}$ till they were run on a Canto flow cytometer (BD Biosciences, San Jose, CA) and analyzed using FlowJo software (Tree Star, Ashland, OR).
A

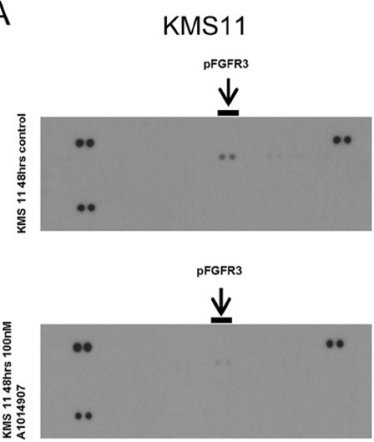

B

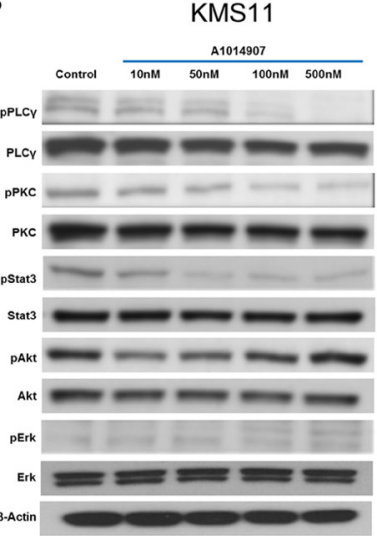

C

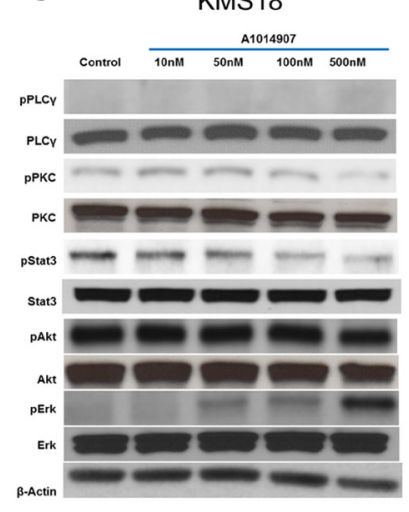

$\mathrm{D}$

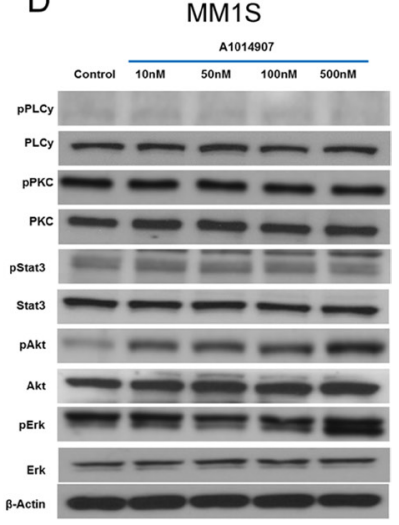

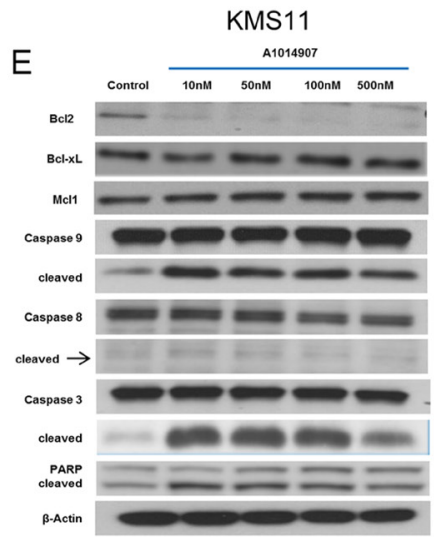
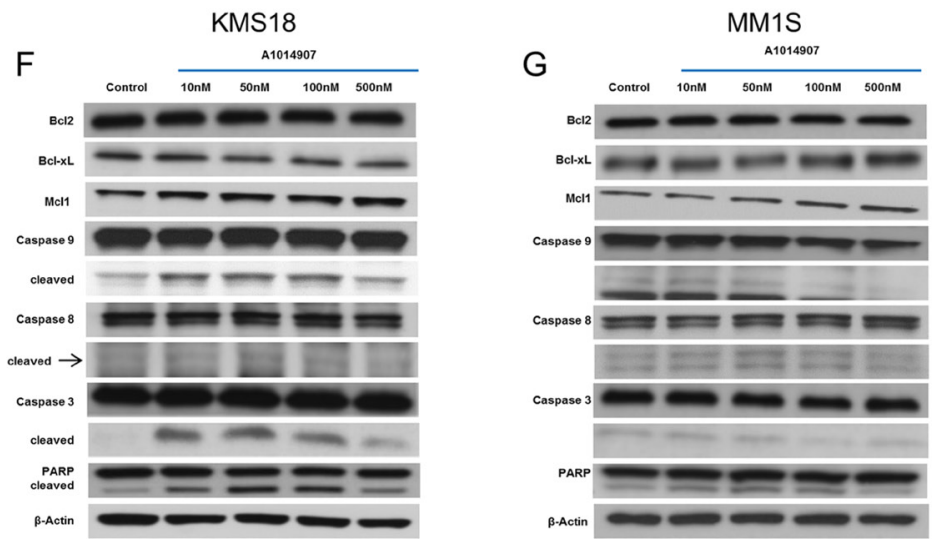

Figure 5: (A) KMS11 cells were left untreated (top panel) or treated with $100 \mathrm{nM}$ of A1014907 for 48 hrs. A receptor tyrosine kinase array was then performed and we observed down regulation of pFGFR3 levels post drug treatment. (B) KMS11, (C) KMS18 and (D) MM1S cells were treated with indicated concentrations of A1014907 for $48 \mathrm{hrs}$ and the expression levels of canonical pathway members activated by FGFR3, namely PLC $\gamma$, PKC, Stat3, Akt and Erk were examined by western blotting. (E) KMS11, (F) KMS18 and (G) MM1S cells were treated with indicated concentrations of A1014907 for $48 \mathrm{hrs}$ and the expression levels of caspases, PARP, Bcl2, Bcl-Xl and Mcl1 were examined by western blotting. 


\section{Apoptosis assays}

Apoptosis induction by A1014907 in MM cell lines and patient cells was measured by annexin V/PI staining and flow cytometry [38-40]. Briefly, cells were washed twice in Annexin Binding Buffer (ABB) (10 mM HEPES pH 7.4, $140 \mathrm{mM} \mathrm{NaCl}, 2.5 \mathrm{mM} \mathrm{CaCl} 2) .100 \mu \mathrm{l}$ cells $\left(10^{7}\right.$ cells $\left./ \mathrm{ml}\right)$ were stained with $3 \mu \mathrm{l}$ of annexin V-FITC (Caltag, Burlingame, CA) for 15 minutes at room temperature. Cells were again washed with $\mathrm{ABB}$ and resuspended in $500 \mu \mathrm{l} \mathrm{ABB}$ containing $5 \mu \mathrm{l}$ of $1 \mathrm{mg} / \mathrm{ml} \mathrm{PI}$ (Sigma-Aldrich) and run on a Canto flow cytometer (BD Biosciences).

\section{Western blotting}

Cells were lysed in RIPA buffer (50 mM HEPES (pH 7.4), $150 \mathrm{mM} \mathrm{NaCl}, 1 \%$ Triton X-100, $30 \mathrm{mM}$ sodium pyrophosphate, $5 \mathrm{mM}$ EDTA) containing Halt Phosphatase Cocktail (Thermo Fisher Scientific, Rockford, IL), $1 \mathrm{mM}$ phenylmethylsulfonyl-fluoride (PMSF) (Thermo
Fischer) and protease inhibitor cocktail (PIC) (SigmaAldrich). Protein lysate concentrations were measured using BCA assay (Thermo Fisher). Equal amounts of protein were loaded on Tris-Glycine gels and transferred onto nitrocellulose membranes (Bio-Rad, Hercules, CA). All antibodies were purchased from Cell Signaling Technology (Danvers, MA). Antigen-antibody complexes were detected using enhanced chemiluminescence (GE Healthcare, Piscataway, NJ).

\section{Receptor tyrosine kinase (RTK) array}

Human phosphor-RTK array was obtained from R\&D Systems Inc, which allowed simultaneous screening of 49 different phosphorylated RTK's. The array was processed following the manufacturer's instructions. Briefly, protein extracts obtained from untreated or drug treated cells were added onto antibody coated nitrocellulose membrane After overnight incubation at $4^{\circ} \mathrm{C}$, the membrane was washed to remove excess antibodies and incubated with anti phospho tyrosine HRP Detection

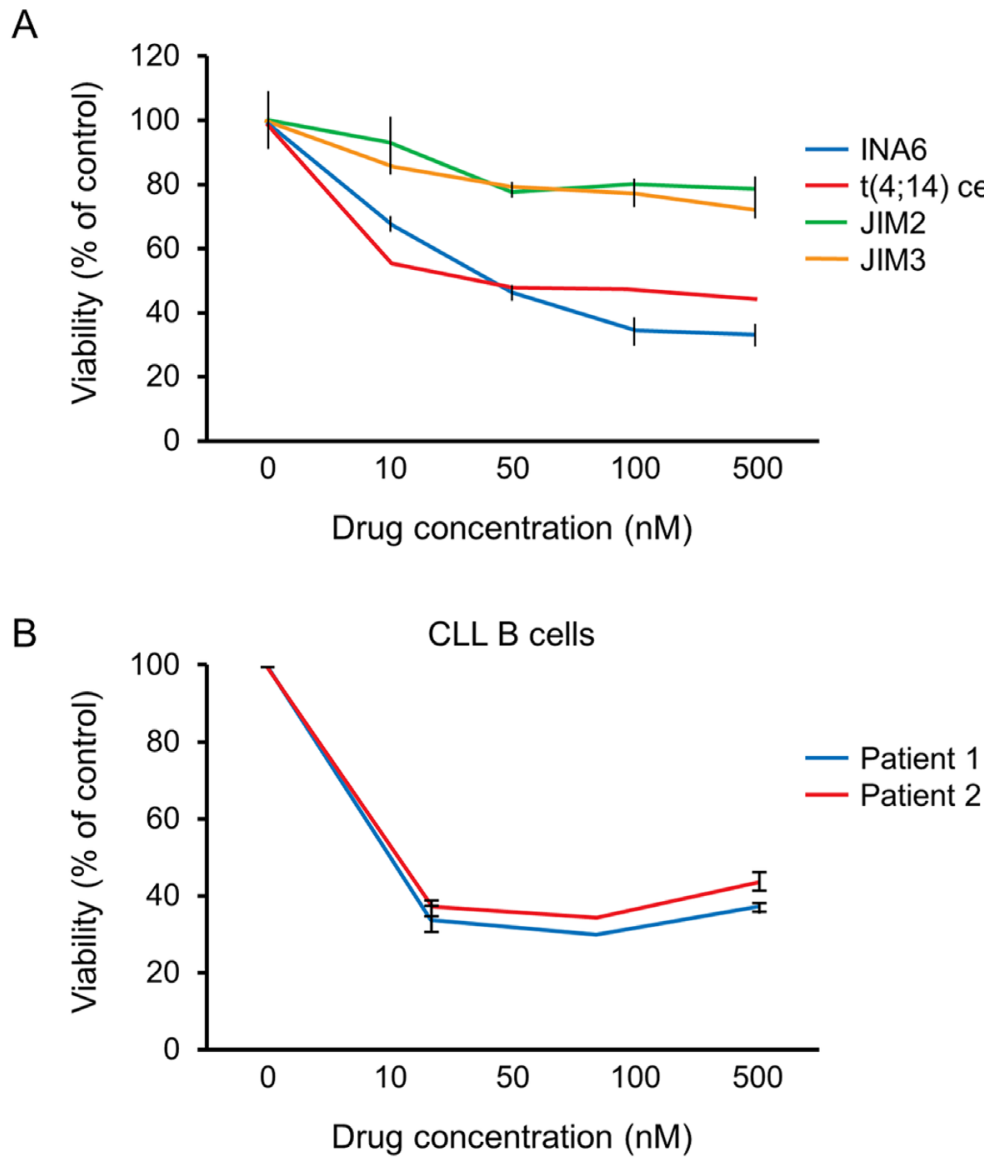

Figure 6: (A) INA6, JIM2 and JIM3 were exposed to indicated doses of A1014907. A1014907 induced significantly more cytotoxicity in INA6 when compared to JIM2 and JIM3. The cytotoxicity induced in INA6 was similar to the mean cytotoxicity induced in cell lines with $\mathrm{t}(4 ; 14)$ translocation. The mean cytotoxicity was calculated from the results shown in Figure 1A. (B) CLL B cells from two patients were treated with indicated doses of A1014907 for 72 hrs. A1014907 induced potent cytotoxicity in both the patient cells similar to our observations on FGFR3 positive MM cell lines. 
antibody for two hours followed by detection of the antigen antibody complex using chemiluminescence.

\section{FGFR3 expression by flow cytometry}

The CLL patient cells were obtained after informed consent and processed and stained for surface FGFR3 expression as described elsewhere [27].

\section{Statistical analyses}

All experiments were performed thrice and the error bars represent one standard deviation. Students $t$ test was used to examine significance in Figure $1 \mathrm{E}$ and $1 \mathrm{~F}$.

\section{ACKNOWLEDGMENTS}

We would like to acknowledge Kimberly Henderson, Roberta DeGoey and Beatrice Hartke for their assistance with processing of tumor cells and all of the patients who provided us with the tumor samples. We would also like to thank Dr. Neil Kay, Dr. Sutapa Sinha and Mr. Justin Boysen for providing the CLL B cells. Also, we thank Mr. Boysen for examining FGFR3 expression on the CLL B cells by flow cytometry.

\section{CONFLICTS OF INTEREST}

SK: research support from Celgene, Millennium, Novartis, Merck, Cephalon, Genzyme and Bayer. SK: advisory board- Merck.

\section{GRANT SUPPORT}

This study was supported in part by Hematological Malignancies Program (Mayo Clinic Cancer Center); and CA90628 (SK) from National Cancer Institute. This work was funded by the Predolin Foundation, Mayo Clinic Hematology Small Grants Program, International Myeloma Foundation, Mayo Clinic Multiple Myeloma SPORE, Wendy Will Case Cancer Fund, and Mayo Clinic Development Funds from the Myeloma, Amyloidosis and Dysproteinemia Disease Oriented Group.

A1014907 was synthesized and provided by Abbott Laboratories Ltd under a Material Transfer Agreement (MTA).

\section{REFERENCES}

1. Glover DM, Leibowitz MH, McLean DA, Parry H. Mutations in aurora prevent centrosome separation leading to the formation of monopolar spindles. Cell. 1995; 81:95-105.

2. Kimura M, Kotani S, Hattori T, Sumi N, Yoshioka T, Todokoro K, Okano Y. Cell cycle-dependent expression and spindle pole localization of a novel human protein kinase,
Aik, related to Aurora of Drosophila and yeast Ipl1. J Biol Chem. 1997; 272:13766-13771.

3. Zhou H, Kuang J, Zhong L, Kuo WL, Gray JW, Sahin A, Brinkley BR, Sen S. Tumour amplified kinase STK15/ BTAK induces centrosome amplification, aneuploidy and transformation. Nat Genet. 1998; 20:189-193.

4. Stenoien DL, Sen S, Mancini MA, Brinkley BR. Dynamic association of a tumor amplified kinase, Aurora-A, with the centrosome and mitotic spindle. Cell Motil Cytoskeleton. 2003; 55:134-146.

5. Giet R, Prigent C. Aurora/Ipl1p-related kinases, a new oncogenic family of mitotic serine-threonine kinases. J Cell Sci. 1999; 112:3591-3601.

6. Adams RR, Wheatley SP, Gouldsworthy AM, KandelsLewis SE, Carmena M, Smythe C, Gerloff DL, Earnshaw WC. INCENP binds the Aurora-related kinase AIRK2 and is required to target it to chromosomes, the central spindle and cleavage furrow. Curr Biol. 2000; 10:1075-1078.

7. Andrews PD, Ovechkina Y, Morrice N, Wagenbach M, Duncan K, Wordeman L, Swedlow JR. Aurora B regulates MCAK at the mitotic centromere. Dev Cell. 2004; 6:253-268.

8. Goto H, Yasui Y, Kawajiri A, Nigg EA, Terada Y, Tatsuka M, Nagata K, Inagaki M. Aurora-B regulates the cleavage furrow-specific vimentin phosphorylation in the cytokinetic process. J Biol Chem. 2003; 278:8526-8530.

9. Sasai K, Katayama H, Stenoien DL, Fujii S, Honda R, Kimura M, Okano Y, Tatsuka M, Suzuki F, Nigg EA, Earnshaw WC, Brinkley WR, Sen S. Aurora-C kinase is a novel chromosomal passenger protein that can complement Aurora-B kinase function in mitotic cells. Cell Motil Cytoskeleton. 2004; 59:249-263.

10. Nair JS, Ho AL, Schwartz GK. The induction of polyploidy or apoptosis by the Aurora A kinase inhibitor MK8745 is p53-dependent. Cell Cycle. 2012; 11:807-817.

11. Qin L, Tong T, Song Y, Xue L, Fan F, Zhan Q. Aurora-A interacts with Cyclin B1 and enhances its stability. Cancer Lett. 2009; 275:77-85.

12. Li JP, Yang YX, Liu QL, Pan ST, He ZX, Zhang X, Yang T, Chen XW, Wang D, Qiu JX, Zhou SF. The investigational Aurora kinase A inhibitor alisertib (MLN8237) induces cell cycle G2/M arrest, apoptosis, and autophagy via p38 MAPK and Akt/mTOR signaling pathways in human breast cancer cells. Drug Des Devel Ther. 2015; 9:1627-1652.

13. Hauf S, Cole RW, LaTerra S, Zimmer C, Schnapp G, Walter R, Heckel A, van Meel J, Rieder CL, Peters JM. The small molecule Hesperadin reveals a role for Aurora $\mathrm{B}$ in correcting kinetochore-microtubule attachment and in maintaining the spindle assembly checkpoint. J Cell Biol. 2003; 161:281-294.

14. Saurin AT, van der Waal MS, Medema RH, Lens SM, Kops GJ. Aurora B potentiates Mps 1 activation to ensure rapid checkpoint establishment at the onset of mitosis. Nat Commun. 2011; 2:316. 
15. Manchado E, Guillamot M, Malumbres M. Killing cells by targeting mitosis. Cell Death Differ. 2012; 19:369-377.

16. Chng WJ, Braggio E, Mulligan G, Bryant B, Remstein E, Valdez R, Dogan A, Fonseca R. The centrosome index is a powerful prognostic marker in myeloma and identifies a cohort of patients that might benefit from aurora kinase inhibition. Blood. 2008; 111:1603-1609.

17. Wang X, Sinn AL, Pollok K, Sandusky G, Zhang S, Chen L, Liang J, Crean CD, Suvannasankha A, Abonour R, Sidor C, Bray MR, Farag SS. Preclinical activity of a novel multiple tyrosine kinase and aurora kinase inhibitor, ENMD-2076, against multiple myeloma. Br J Haematol. 2010; 150:313-325.

18. Gorgun G, Calabrese E, Hideshima T, Ecsedy J, Perrone G, Mani M, Ikeda H, Bianchi G, Hu Y, Cirstea D, Santo L, Tai YT, Nahar S, et al. A novel Aurora-A kinase inhibitor MLN8237 induces cytotoxicity and cell-cycle arrest in multiple myeloma. Blood. 2010; 115:5202-5213.

19. Evans RP, Naber C, Steffler T, Checkland T, Maxwell CA, Keats JJ, Belch AR, Pilarski LM, Lai R, Reiman T. The selective Aurora B kinase inhibitor AZD1152 is a potential new treatment for multiple myeloma. Br J Haematol. 2008; 140:295-302.

20. Santo L, Hideshima T, Cirstea D, Bandi M, Nelson EA, Gorgun G, Rodig S, Vallet S, Pozzi S, Patel K, Unitt C, Squires M, Hu Y, et al. Antimyeloma activity of a multitargeted kinase inhibitor, AT9283, via potent Aurora kinase and STAT3 inhibition either alone or in combination with lenalidomide. Clin Cancer Res. 2011; 17:3259-3271.

21. Negri JM, McMillin DW, Delmore J, Mitsiades N, Hayden P, Klippel S, Hideshima T, Chauhan D, Munshi NC, Buser CA, Pollard J, Richardson PG, Anderson KC, et al. In vitro anti-myeloma activity of the Aurora kinase inhibitor VE-465. Br J Haematol. 2009; 147:672-676.

22. Podar K, Richardson PG, Hideshima T, Chauhan D, Anderson KC. The malignant clone and the bone-marrow environment. Best Pract Res Clin Haematol. 2007; 20:597-612.

23. Burke B, Ellenberg J. Remodelling the walls of the nucleus. Nat Rev Mol Cell Biol. 2002; 3:487-497.

24. Guttinger S, Laurell E, Kutay U. Orchestrating nuclear envelope disassembly and reassembly during mitosis. Nat Rev Mol Cell Biol. 2009; 10:178-191.

25. Chesi M, Brents LA, Ely SA, Bais C, Robbiani DF, Mesri EA, Kuehl WM, Bergsagel PL. Activated fibroblast growth factor receptor 3 is an oncogene that contributes to tumor progression in multiple myeloma. Blood. 2001; 97:729-736.

26. Kalff A, Spencer A. The $t(4 ; 14)$ translocation and FGFR3 overexpression in multiple myeloma: prognostic implications and current clinical strategies. Blood Cancer J. 2012; 2:e89.
27. Sinha S, Boysen J, Nelson M, Warner SL, Bearss D, Kay NE, Ghosh AK. Axl activates fibroblast growth factor receptor pathway to potentiate survival signals in B-cell chronic lymphocytic leukemia cells. Leukemia. 2016; 30:1431-1436.

28. Kumar S, Fonseca R, Ketterling RP, Dispenzieri A, Lacy MQ, Gertz MA, Hayman SR, Buadi FK, Dingli D, Knudson RA, Greenberg A, Russell SJ, Zeldenrust SR, et al. Trisomies in multiple myeloma: impact on survival in patients with high-risk cytogenetics. Blood. 2012; 119:2100-2105.

29. Rajkumar SV. Treatment of multiple myeloma. Nat Rev Clin Oncol. 2011; 8:479-491.

30. Fonseca R, Bergsagel PL, Drach J, Shaughnessy J, Gutierrez N, Stewart AK, Morgan G, Van Ness B, Chesi M, Minvielle S, Neri A, Barlogie B, Kuehl WM, et al. International Myeloma Working Group molecular classification of multiple myeloma: spotlight review. Leukemia. 2009; 23:2210-2221.

31. Chesi M, Bergsagel PL, Brents LA, Smith CM, Gerhard DS, Kuehl WM. Dysregulation of cyclin D1 by translocation into an IgH gamma switch region in two multiple myeloma cell lines. Blood. 1996; 88:674-681.

32. Shaughnessy J Jr, Gabrea A, Qi Y, Brents L, Zhan F, Tian E, Sawyer J, Barlogie B, Bergsagel PL, Kuehl M. Cyclin D3 at 6 p21 is dysregulated by recurrent chromosomal translocations to immunoglobulin loci in multiple myeloma. Blood. 2001; 98:217-223.

33. Zhan F, Tian E, Bumm K, Smith R, Barlogie B, Shaughnessy J Jr. Gene expression profiling of human plasma cell differentiation and classification of multiple myeloma based on similarities to distinct stages of latestage B-cell development. Blood. 2003; 101:1128-1140.

34. Moreau P, Cavo M, Sonneveld P, Rosinol L, Attal M, Pezzi A, Goldschmidt H, Lahuerta JJ, Marit G, Palumbo A, van der Holt B, Blade J, Petrucci MT, et al. Combination of international scoring system 3 , high lactate dehydrogenase, and $\mathrm{t}(4 ; 14)$ and/or del(17p) identifies patients with multiple myeloma (MM) treated with front-line autologous stem-cell transplantation at high risk of early MM progression-related death. J Clin Oncol. 2014; 32:2173-2180.

35. Vatsveen TK, Brenne AT, Dai HY, Waage A, Sundan A, Borset M. FGFR3 is expressed and is important for survival in INA-6, a human myeloma cell line without a $\mathrm{t}(4 ; 14)$. Eur J Haematol. 2009; 83:471-476.

36. Quintero-Rivera F, El-Sabbagh Badr R, Rao PN. FGFR3 amplification in the absence of IGH@-FGFR3 fusion $\mathrm{t}(4 ; 14)$ in myeloma. Cancer Genet Cytogenet. 2009; 195:92-93.

37. Kline MP, Rajkumar SV, Timm MM, Kimlinger TK, Haug JL, Lust JA, Greipp PR, Kumar S. ABT-737, an inhibitor of Bcl-2 family proteins, is a potent inducer of apoptosis in multiple myeloma cells. Leukemia. 2007; 21:1549-1560. 
38. Ramakrishnan V, Ansell S, Haug J, Grote D, Kimlinger T, Stenson M, Timm M, Wellik L, Halling T, Rajkumar SV, Kumar S. MRK003, a gamma-secretase inhibitor exhibits promising in vitro pre-clinical activity in multiple myeloma and non-Hodgkin's lymphoma. Leukemia. 2012; 26:340-348.

39. Ramakrishnan V, Kimlinger T, Haug J, Painuly U, Wellik L, Halling T, Rajkumar SV, Kumar S. Anti-myeloma activity of Akt inhibition is linked to the activation status of PI3K/ Akt and MEK/ERK pathway. PLoS One. 2012; 7:e50005.
40. Ramakrishnan V, Painuly U, Kimlinger T, Haug J, Rajkumar SV, Kumar S. Inhibitor of apoptosis proteins as therapeutic targets in multiple myeloma. Leukemia. 2014; 28:1519-1528. 